\title{
English language programme for periodontologists
}

\section{Annette Reumert-Kazes}

\section{OpenEdition}

\section{Journals}

Electronic version

URL: http://journals.openedition.org/asp/4374

DOI: $10.4000 /$ asp.4374

ISSN: 2108-6354

\section{Publisher}

Groupe d'étude et de recherche en anglais de spécialité

\section{Printed version}

Date of publication: 1 March 1993

Number of pages: $251-277$

ISSN: 1246-8185

\section{Electronic reference}

Annette Reumert-Kazes, «English language programme for periodontologists », ASp [Online], 1 | 1993, Online since 30 April 2014, connection on 30 April 2019. URL : http://journals.openedition.org/ asp/4374; DOI : 10.4000/asp.4374

This text was automatically generated on 30 April 2019

Tous droits réservés 


\title{
English language programme for periodontologists
}

\author{
Annette Reumert-Kazes
}

\section{The ESP teacher and science}

1 What happens to a linguist when faced with the task of teaching ESP to scientists? I am talking of the "normal", average English language teacher, in France the agrégé or certifié for example, whose education is heavily, not to say exclusively, Arts-oriented, who was trained to deal with literary texts, with language for everyday communicative purposes, and with grammar; who has frequently used journalistic and perhaps even economic texts in his or her own teaching, but who has never analyzed authentic scientific prose. I am talking about people like us here, who feel close to the language used in Arts-andSocial-Sciences-oriented texts, because this is language we understand and feel we participate in creating and controlling. But what happens to us the day we are approached by a physicist, a mathematician, or a group of doctors, who want us to help them correct their articles for this or that specialized journal, to teach them the English they need to understand or write such articles, or to present a paper at a symposium?

2 By analogy with the well-known term "culture shock" I have decided to use the expression "science shock" here to describe the state a language teacher may be plunged into, when faced with having to understand and possibly translate a word like Temporomandibular joint pain-dysfunction syndrome, ${ }^{1}$ or simply say a sentence like:

The correlation was statistically significant; $\mathrm{X}^{2}=12.74, \mathrm{P}<0.02$ (CHI square four equals twelve point seventy four, probability smaller than zero point zero two)

Such words, expressions and sentences appear very frequently in scientific texts, and not only do we linguists have trouble understanding them, we often do not even know how to say them. Let us look at a few examples: What do the following enigmatic abbreviations and signs refer to: $1000 \mathrm{ppm}$ fluoride or $1000 \mu \mathrm{g} / \mathrm{ml} ?^{2}$ And how to pronounce and stress the word hydroxyphenyl? Not to mention trichlorohydroxyphenyl? Or chlorhexidine? Such terms are neither to be found in ordinary dictionaries, nor in Daniel Jones' English 
Pronouncing Dictionary. And should they ever appear in a specialized glossary, only their definition will be given, never their pronunciation.

4 My point here is that most linguists are cut off from the scientific world much too early in their career, or rather in their education, and thus do not participate in creating the language scientists use to report on their experiments and findings. When suddenly asked to deal with scientific literature, the language teacher may have to swallow many a stupid question, but also many a critical remark concerning style and grammar, because, whether one likes it or not, it is different from more Arts-oriented prose. Not that I belong to those who claim that scientific English prose has a grammar of its own; that is going too far. Still, one does find certain particularities, even grammatical, as we shall see later.

5 In addition to adapting to the particularities of scientific style, the language teacher must of course also learn the specific terms of this or that special field, and this cannot be done without learning something about the field itself. So, altogether, the English language teacher, whether of anglophone, francophone or other origin, is in for a great deal of "updating" when he or she embarks upon the challenging adventure of helping (French) scientists understand scientific texts in English and express themselves in English about their work.

\section{Periodontology}

6 Five years ago, I was called upon to set up and teach an English course to a group of dentists specializing in periodontology, at the University of Paris 7, Jussieu, and I have been teaching that class ever since.

7 What is periodontology? It is defined as:

the scientific study of the periodontium in health and disease", the periodontium being "the tissues that invest and support the teeth : gingiva, alveolar mucosa, cementum, periodontal membrane, and the alveolar and supporting bone. (GPT 1986)

8 Figures 1 and 2 show profile cuts of, respectively, a first lower molar and a first upper molar, both seen in profile. 
Figure 1

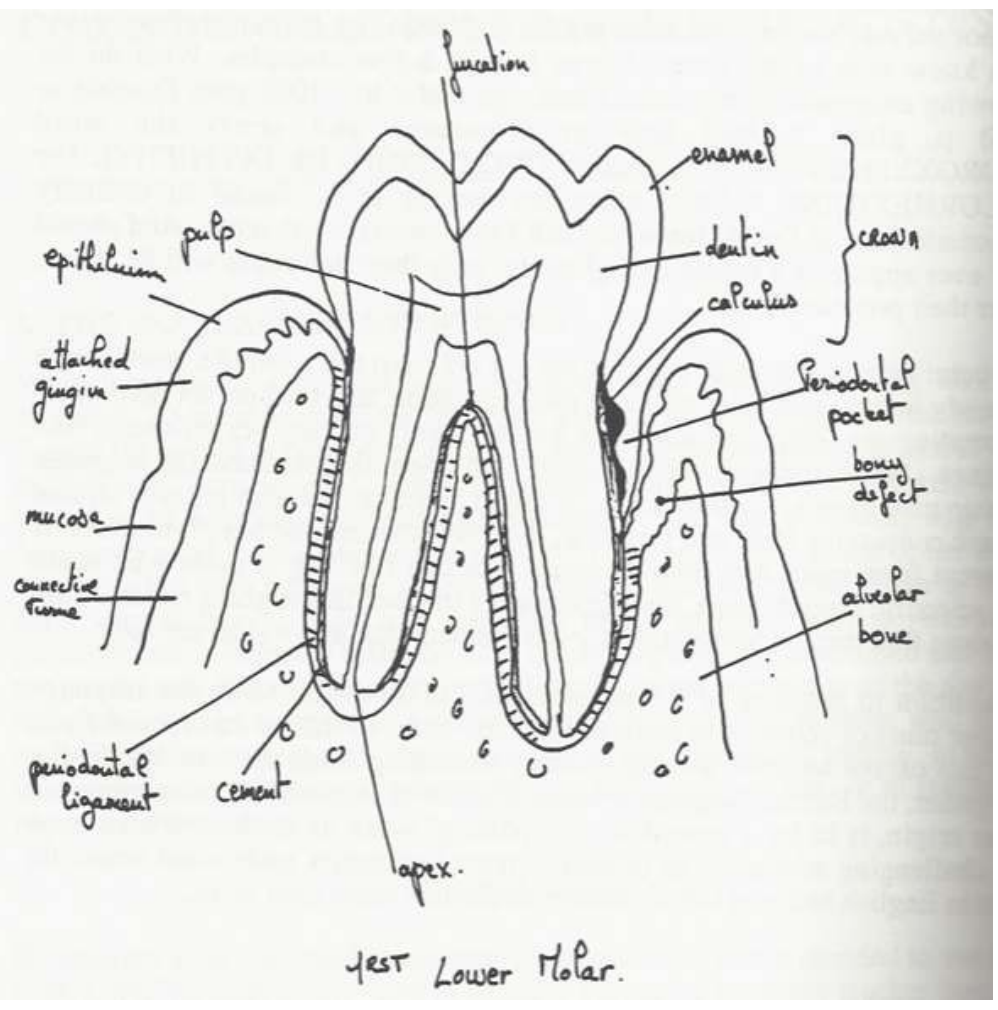

Figure 2

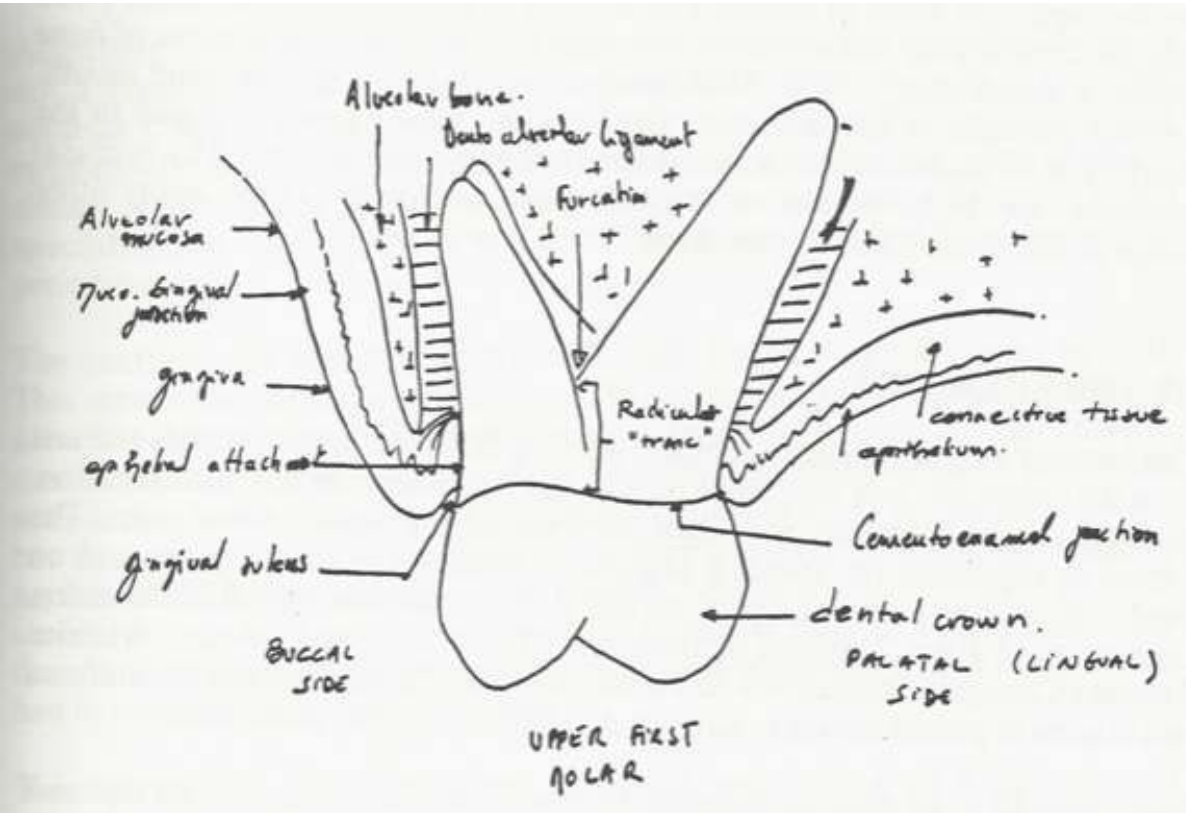

Most of us here being language teachers provided with tongues, many of us in fact speaking several, we all have mouths and we all have teeth, and so I thought it might interest you to throw a glance at these drawings (i.e. figures 1 and 2) made by two of my periodontology students, be it only to get an idea of the complexity of the human mouth, 
and along with that, an idea of the complexity of periodontic terminology. It struck me, when I first became familiar with this field, that every square millimeter within the mouth, or the oral cavity as it is called, has a name of its own, and I think these drawings bring that out fairly well. Notice the periodontal pocket (poche parodontale), the calculus deposit (tartre) and the bony defect in the lower molar (fig. 1). Such problems, if not dealt with in time, may lead to THE disease that preoccupies periodontists, namely periodontitis.

While we are looking at these drawings I would like to mention a linguistic phenomenon concerning the term furcation. As you can see, and as defined by GPT (1986), furcation (or furca) is "the anatomic area of a multirooted tooth where the roots diverge". However, both the English furcation and the French "furcation" have come to signify not only that area, but also the typical problem occurring there, the correct terms for which are furca(tion) invasion or furcation involvement. So when in French you are told "Vous avez une furcation", you may be certain your dentist refers to a case of "pathologic resorption of bone within a furca(tion)" (GPT 1986) and not simply to a spot in your mouth. Another example of this linguistic phenomenon, which seems to found in the expression occlusal trauma, which refers both to the trauma caused by occlusal overload, and to the problem of occlusal overload itself. Like so many other things in this discipline, this phenomenon was new to me.

\section{The learners}

11 The learners are fully-fledged dentists, working full-time in their clinics in Paris or in the provinces, and who come back to the University for this specialization, to which they devote a day and a half per week, over a period of four years. The course is organized on Tuesday afternoons from 2 p.m. to 10 p.m., and on Wednesdays from 8 a.m. to 8 p.m., all this at the Garancière School of Dentistry, University of Paris 7, which delivers the DUESCP = Diplôme Universitaire d'Etudes Cliniques Spécialisées de Parodontologie. The students attend seminars and classes in periodontology and also do practical clinical work there.

12 Every year 12 to 14 students make up the group, but due to the way this diploma was first set up, the group always consists of a mixture of 1st, 2nd, 3rd and 4th-year students, who study together.

13 Every year 3 students leave the group and three new come in, and thus the group is renewed progressively. Figure 3 below illustrates this phenomenon, over a 4-year-period:

Figure 3

\begin{tabular}{|l|l|l|l|l|}
\hline & 1st year students & 2nd year students & 3rd year students & 4th year students \\
\hline 1988 & JKL & GHI & DEF & ABC \\
\hline 1989 & MNO & JKL & GHI & DEF \\
\hline 1990 & PQR & MNO & JKL & GHI \\
\hline 1991 & STU & PQR & MNO & JKL \\
\hline
\end{tabular}


Progressive renewal of the group of twelve students. Each year the group consists of an equal mixture of 1st, 2nd, 3rd, and 4th year students. The letters A, B, C ... U represent individual students, $A B C$ being the "oldest", STU the "youngest" 3-student sub-group. These two sub-groups started specializing in 1985 and 1991 respectively.

According to the students and their Garancière teachers, this mixing of levels is not a problem as far as periodontology instruction is concerned, and thus students $\mathrm{L}$ and $\mathrm{B}$ for example, who in 1988 were in their first and fourth year respectively, did not feel uncomfortable or bored attending the same dentistry classes. I should add that all students start out in first year with some initial specialization, having taken a CES ( Certificat d'Etudes Supérieures) in periodontology.

6 The configuration described in figure 3 holds for the English classes as well. This means that the same student comes to Jussieu, on a Tuesday afternoon, for a weekly 3-hour class in English four years in a row, getting 25 hours a year, over a period of 8 or 9 weeks, from December to mid-February. He or she attends the classes in the company of his/her fellow-students as described above, but in terms of levels of English, the mixture is erratic, because the students arrive with different backgrounds in English. Let me give an example: in 1991, student S joined the group. She turned out to master English a great deal better than student $\mathrm{K}$, who had already had 3 years of English with me. Yet, these two had to attend English classes together.

7 This situation is not an easy one to handle, and setting up a grammatical progression, for example, is simply not possible, given that when the 4th year students should be ready to tackle complicated structures with modal verbs and the second conditional, the first year students may still be struggling with the difference between the simple and continuous present tenses - unless they were advanced at their arrival, which they never are all of them, homogeneously.

8 Thus, more or less all grammar points have to be covered every year, each year putting particular stress on one or two specific phenomena.

Another difficulty is that one can never use the same supporting material two years in a row. New articles, new texts have to be found and prepared for didactic use every year, and that represents a great deal of work for the teacher.

At this point I would like to briefly address the theme that Anne Pradeilles dealt with yesterday, namely knowledge of the speciality versus knowledge of English, seen from the learners' as well as from the ESP teacher's point of view. Figure 4 illustrates the initial situation, year zero, when an ESP teacher starts out knowing practically nothing about her students' speciality. 


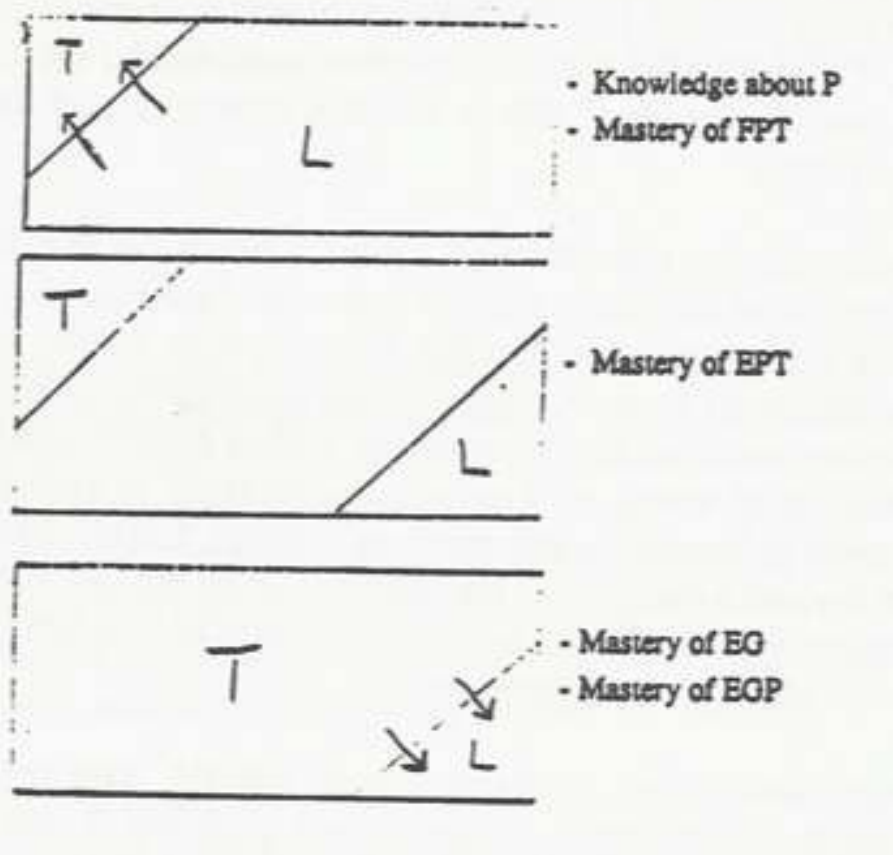

$\mathrm{L}=$ Learner; $\mathrm{T}=$ Teacher; $\mathrm{P}=$ Periodontology (the science); FPT / EPT = French / English Periodontic Terminology; EGP/ EG = English Grammar/English for General Purposes

Box 1 shows the initially ignorant teacher being taught periodontology by his or her students. Box 2 illustrates everybody's initial ignorance in EPT. Box 3 gives the classical picture of the English-forGeneral-Purposes teacher helping his/ her students.

Although, with time, the teacher acquires some knowledge in P, in FPT, and in EPT, there will always be room for a lot of box-1-type interaction, and that is precisely one of the most interesting aspects of ESP teaching as far as I am concerned ("l'enseignant enseigné").

\section{Purposes, methods and materials}

What do the learners need English for, really? Here I would like to come back to what Ludmilla Delorme said: the Institution is one thing, the learners is another.

The Institution wants the learners to be able to:

- read scientific articles written in English, and understand them, so as to be able to report on them, in French, in front of their periodontology teachers and fellow students at Garancière,

- understand oral English, which they need for the seminars given by foreign speakers at Garancière, and at the international congress meetings the students get to attend during (and possibly after) their specialization period. And let me add here that of course far from all foreign dentist speakers are anglophone: Scandinavian, German, and even Japanese periodontologists visit France and attend congress meetings, so that the students must learn to understand not only the English of the English, but various other dialects of that beautiful language. I will not have time to deal with this aspect of my teaching here, although it is both challenging and amusing,

- speak English, as clearly and as correctly as possible, so as to be able to ask questions and discuss with foreign colleagues on these international occasions. 
24 necessarily coincide with the Institution's. Many rate the skills to be developed as follows: 1) improvement of comprehension of spoken English; 2) improvement of grammar; 3) improvement of pronunciation; 4) learning dentistry-oriented terminology.

One student, B.B., wrote the following about his wishes concerning English:

Ce que je souhaite, c'est acquérir les nuances indispensables à la compréhension de ce que veut vraiment dire l'orateur. C'est très important pour nous, en parodontologie, de saisir le détail, le doute, la nuance exprimée par le bon mot, au bon endroit. C'est d'ailleurs très important aussi dans la vie courante: ne pas pouvoir exprimer ou comprendre la différence entre une viande salée, peu salée, un peu salée, légèrement salée, à peine salée, ou plutôt salée peut amener à de désagréables surprises. Cet exemple montre l'importance de ces petits mots que je souhaite assimiler. Mon but est donc d'acquérir le sens des nuances... Et je souhaite aussi éviter des fautes grammaticales grossières.

It is clear that the students want to improve their English not only for professional purposes, but also for their personal enrichment. This does not necessarily clash with the demands of the Institution, it adds to them. So the one hundred hours of English each student gets in this curriculum are definitely not too many. But it is a shame that they are spread out over four years.

What is done in the classroom? The time is divided between:

- reading/translating/paraphrasing/summing up/discussing scientific articles and doing grammar and vocabulary exercises related to these;

- presentation of periodontic cases by the students in English (one per session) and correction of these presentations, which are systematically taped, sometimes video-filmed (model correction sheet used for Oral Presentations annexed);

- language-laboratory work; listening to $\mathrm{BBC}$ news bulletins and radio interviews, watching videoed television programs, and exploiting all such oral input; learning to pronounce words, in particular scientific terms (chemical solutions, periodontic diseases, instruments, etc.) using IPA transcriptions;

- studying/analyzing/discussing different kinds of non-scientific texts (the press, short stories, novels, etc.).

No ESP textbook or other kind of didactic material is available in this speciality, but of course it is possible to use certain texts conceived for medical students, or simply for scientists broadly speaking. Thus I have adapted a few units of Medically Speaking (Sandler, 1982) to dentists, for use in the language lab, and have welcomed the arrival on the market of Minimum Competence in Scientific English (Upjohn, Blattes \& Jans 1991).

There will be little time to deal with material in detail, but I would like us to examine together some extracts from periodontic and medical texts, in particular of the kind that students find difficult, this for various reasons as we shall see:

(a) Subgingival calculus is considered a resultant of subgingival bacterial plaque accumulation and is ascribed a secondary role in the pathology of periodontitis. The expected lack of correlation of the initial amount of subgingival calculus and long-term response was borne out. (Wasserman, Hirschfeld 1988)

The difficulty here is the verb bear out, which some students took to mean rule out (which had been studied shortly before). I found this mistake very logical and had to go into some detail explaining the various semantic functions of the postposition out depending on the verb it is linked with. Thus, in rule out it is ascribed the meaning it has in the 
phrasal verb throw out ("faire sortir d'une certaine existence", donc, éliminer) and in bear out the meaning found in bring out ("faire sortir du domaine non-connu ou non-certain", donc, mettre en évidence), the verbs bring and throw indicating more clearly than bear and rule the respective movements towards the speaker (and thus "into existence") and away from the speaker (and thus "into non-existence").

The point I want to stress here - and which I am sure you all agree with - is that the profound difficulties about ESP lie, not in the specific terminology attached to it, but in the English language itself, in its syntax, grammar, and in the complexity of its vocabulary: words with several meanings, words belonging to different grammatical categories, etc. In particular, the phrasal verbs (such as the ones examined above) pose a problem, but so they do with any type of learner, not just with the ESP learner. To the phrasal verbs we must add what student B.B. (quoted above) calls "les petits mots", which Michel Perrin terms "tool words", and which A. Davoust (1983) calls "mots écran": adverbs such as all, almost, also already, although, as, even, ever, hardly, and "groups" of adverbs such as all but, anything but, nothing but, so as to, as of, etc. It is my personal experience that different types of students, the so-called English "specialists" and "non-specialists" alike, turn out to have the same difficulties, with the same phenomena of the English language. And this greatly simplifies any English teacher's task.

Here is an example of a sentence containing clusters of "mots écran":

(b) Although seemingly almost self-evident, it is useful nonetheless to keep in mind the various purposes of the interviewing-evaluating process. (From a medical article, reference lost, my apologies) The difficulty of the next sentence lies in what Michael Alley (1987) calls "compression":

(c) "But more importantly, patient outcome research increasingly points to this particular sequence as enhancing therapeutic outcome." (Same origin as b) Michael Alley (1987) writes the following about scientific papers:

Although complex images and complex language make reading scientific papers difficult, the most taxing aspect of reading scientific papers is compression. Scientific writing is compressed. Most journals impose tight length restrictions on papers. Therefore, scientists must squeeze descriptions of complicated theories and experiments into a few paragraphs, sometimes a few sentences. This compression thickens the writing and greatly increases the concentration required of readers.

Another kind of "compression", due to a well-known type of elliptical structure, is found in the following passages:

(d) Wunderlich et al. reported solutions applied to $4 \mathrm{~mm}$ pockets with a brush or water-jet only penetrated 1.4 to $1.9 \mathrm{~mm}$. (Greenstein 1987)

(e) This data corroborated the work of Yoon and Newman who reported 600 to 1000 ppm killed test microbes and that higher concentrations were more efficient. (Greenstein 1987)

If, in sentence (d), the "missing" link word that had been present (“...reported that solutions...") the students would have found no difficulty understanding it, and would not have confused the two possible meanings of the word solution, namely solution to a problem and liquid substance. The understanding of sentence (e) is facilitated by the presence of that in the second subordinate, but otherwise presents the same problem as $\mathrm{d}$.

As mentioned above, I strongly believe that lack of knowledge about general English language accounts for most comprehension difficulties in ESP. 
Sentences (f), (g), (h) and (i) below contain five fairly common words, namely forward, stepwise, threshold, downhill, and further, one slightly more literary word, doom, and two more science-oriented terms, namely odds and skew. The students were equally bewildered by all of them:

(f) The analysis examined only main effects with forward stepwise selection of variables. (Haffajee et al. 1991)

(g) The relative odds $\left(\mathrm{e}^{\beta}\right)$ associated with a unit change in each variable are given in the right hand column of Table 7. Thus a one year increase is associated with a relative odds of 1.023. (Haffajee et al. 1991)

(h) Sites which exhibited overt gingivitis, visible plaque, [...] attachment levels or gingival recession over certain $\mathrm{mm}$ thresholds or bled on probing were determined. (Haffajee et al. 1991)

(i) Thus, initially advanced cases in this skewed sample population were not doomed to continue downhill, but rather had an equal possibility of remaining stable or undergoing further attachment loss. (Wasserman \& Hirschfeld 1988)

I was able to explain to the students all the difficulties found in sentences (h) and (i), including the term skewed (see fig. 5), to indicate the meanings of the words forward and stepwise as considered separately, and to give them an extensive list of the meanings attached to odds depending on the context. But to this day neither the students nor I are quite sure how to translate into scientific French the expressions forward stepwise selection and relative odds. I do admit that is rather frustrating.

Figure 5. Curve A represents a normal sample population, curve B a skewed sample population

A.

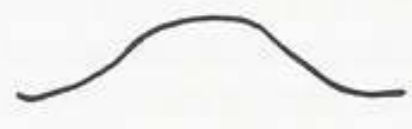

B.

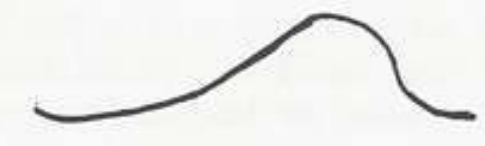

\section{Scientific style, scientific grammar or poor scientific prose?}

I would like to end my presentation with the beginning of an approach to the aspect I find the most interesting and puzzling about scientific writing, namely structural and grammatico-lexical deviations from what linguists consider correct English. Let us examine the following passage:

(j) Case distribution of the study population on the basis of initial gingival reaction were:

(1) non-inflamed $38(33.9 \%)$

(2) moderate $45(40.2 \%)$

(3) severe $29(25.9 \%)$

The amount of subgingival calculus was based on 3x magnification of radiographs and was recorded as follows (Wasserman \& Hirschfeld 1988) 
Clearly, the amount of subgingival calculus located in a patient's mouth can not be based on $3 \times$ magnification of a radiograph, but the measurement of this amount may well be. We are faced here with a "super-elliptical" structure which leaves out, not a "grammar word" like the relative pronoun that (see sentences $d$ and e above), but the "content word" measurement. In other words, this "structure" omits mentioning a phase in the scientific experiment, it skips a step, and by doing so links up two syntactic entities which, brought together, produce a semantic clash. Is this "permitted" because the step in question goes without saying? Most probably yes, because sentence $j$ will be understood not only by any scientist, but by any layman too, including English teachers. What divides the scientists and the laymen is that the former do not mind this "style", whereas the latter do, or at least the linguists among them do. I have encountered - and corrected - this type of error many times before, in particular in the field of astronomy, which I happen to be familiar with, and have come to consider this "step-skipping" trend as typical of scientific prose, or rather, of scientific thought. Because, as Michel Perrin puts it, "the scientists don't read the language, they read the concept."

The question I am putting to you now is: What do we linguists do when asked to deal with such sentences? Do we tell the students, with whom we read these texts, that they are incorrect? Do we correct those we are asked to edit? Personally, I would say yes. But then, are we a purist, hair-splitting minority? Are we not adapting to the scientific mind? What is our role in this community? Can we not "allow" it to develop new language rules, new styles? Or do we - rightly? - consider ourselves "the masters of language"?

Before we get into that discussion, I would like to show you another particularity I have often encountered in scientific papers, namely a specific use of the word using, reduced to signify with:

(k) CO observations were made using the Nobeyama telescope."

(l) Subgingival irrigations were performed using a Water-Pik ${ }^{\bullet}$

The present participle (using) is, in its position here, in principle incompatible with a passive structure : there should be an active agent for it to refer back to. However, we accept this "borderline" type of structure in sentences $\mathrm{k}$ and $\mathrm{l}$, probably assimilating it to an elliptical phrase (... observations were made by someone using...).

Now let us look at three sentences I have made up for the purpose and that come from the layman's world :

(m) $(* ?)$ These pictures were taken using a Nikon camera.

(n) *The room was cleaned using a vacuum cleaner/swept using a broom.

(o) * The letter was written using a thick pen and black ink.

If we question the acceptability of sentence $m$, we certainly do not hesitate to dismiss (n) and (o). And yet, can they not be considered just as "elliptical" as ( $\mathrm{k}$ ) and (l), with justified omission of the "agent-element" by someone? No, it seems they cannot. And is that because sentences ( $\mathrm{k}$ ) and (1) are clearly located in the realm of science, whereas (n) and (o) are not, and (m) only half so? Is such a thing as a specific "grammar" of scientific English discourse in the making? And if so, what other deviating phenomena have been observed?

47 I have no definite answer to these questions, but they interest me greatly and I should be very pleased to work more systematically in this field of "scientific language and thought". 
As it is, I am in the process of elaborating an English-French, French-English didactic dictionary of periodontic terms, a very short extract of which can be found in the Appendix. One of the important aspects of this dictionary, at least in my own eyes, is that all the entries are transcribed in IPA. Another one is that it will contain "language notes", especially addressed to readers and writers of scientific prose, but inspired by the kind one finds in The Longman Dictionary of Contemporary English (1987). I am essentially alone performing this lexicographical task, my dentist colleagues being extremely busy in their own field. However, I should be very glad to have some linguist company, in particular for the translations into French of the examples given in the entries. (This is yet another principle: all terms are to be shown in authentic contexts.) So, I will use this opportunity to make the following announcement: should anybody be interested in collaborating with me on this dictionary, I would be grateful to them for contacting me.

\section{BIBLIOGRAPHY}

Alley, M. 1987. The Craft of Scientific Writing. Englewood Cliffs, NJ: Prentice-Hall, Inc.

Davoust, A. 1983. “À la recherche des mots perdus : pour une politique du réseau dans l'enseignement du lexique”. Les Langues modernes.

Greenstein, G. 1987. "Effects of subgingival irrigation on periodontal status". J. Periodontol Dec., 827-836.

Haffajee A.D., S.S. Socransky, J. Lindhe, R. L. Kent, H. Okamoto \& T. Yoneyama. 1991. “Clinical risk indicators for periodontal attachment loss". J Clin Periodontol 18, 117-125.

Sandler P.L. 1982. Medically Speaking. London: BBC English.

Upjohn J., S. Blattes \& V. Jans. 1991. Minimum Competence in Scientific English. Grenoble: Presses Universitaires de Grenoble.

Wasserman B. \& L. Hirschfeld. 1988. "The relationship of initial clinical parameters to the longterm response in 112 cases of periodontal disease". J Clin Periodontol 15, 38-42

Dictionaries and glossaries

Glossary of Periodontic Terms. 1986. Chicago, IL: American Academy of Periodontology.

Jones D. 1969. English Pronouncing Dictionary. London: Dent \& Sons (E.P. Dutton \& Co. Inc., New York).

Longman Dictionary of Contemporary English. 1987. Burnt Mill, Harlow: Longman Group UK.

\section{APPENDIXES}

Appendix 1. Dictionary of periondontic terms. Extract 


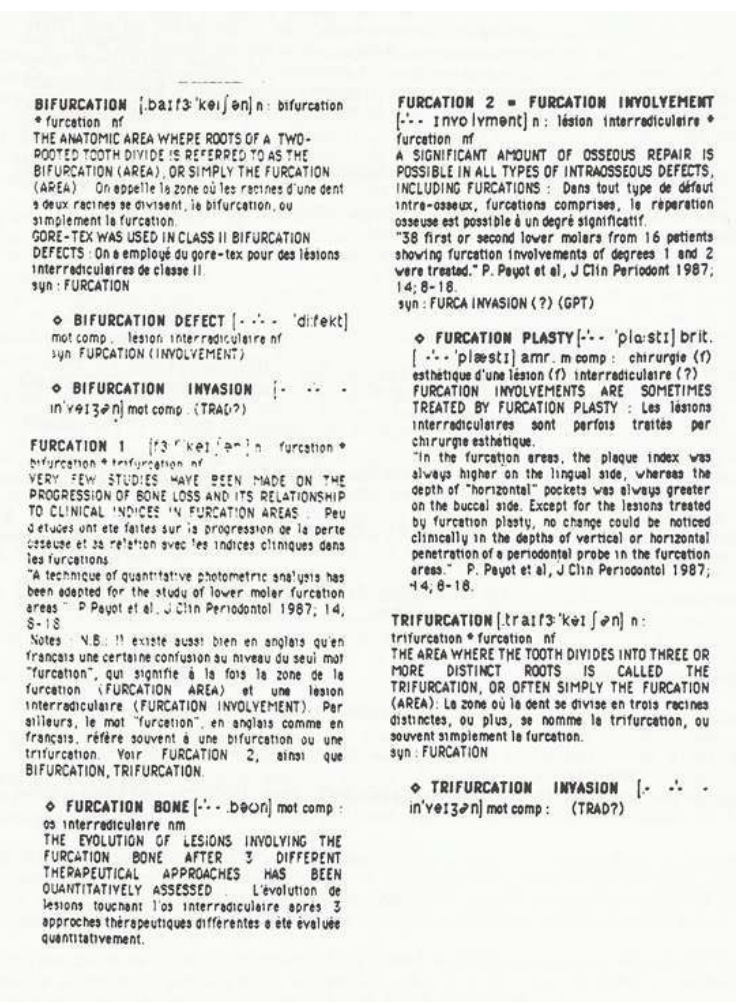

\section{Appendix 2. Discussion minutes}

The first remark came from Professor A. Dudley-Evans who pointed out that abstract language is very much a feature of academic writing, not just in science. Linguists use abstract language too, for linguistics, and literary critics for literary criticism, so abstract language is just as much part of our world, and that is something we have to accept. It was A. Dudley-Evans' impression that I was of that conviction, too, and I certainly agree that Arts-oriented people are perfectly familiar with abstract language as such, it is the scientific subject matters that give them the biggest shock, because they know so little about them. Here A. Dudley-Evans remarked very kindly that the kind of enthusiasm I seem to put into learning about periodontology was enjoyable to see. I thanked him and answered that subject matters connected with health was easier to get involved in than certain other fields.

Professor Michel Perrin agreed and mentioned that mathematics, for example, is a much less gratifying area for us linguists, because more abstract. The degree of abstraction and conceptualization that one must try to reach when helping pure mathematicians understand or present their documents is tremendous, and what there is to learn about that subject matter is not comparable to the more health-oriented sciences, so much "closer" to our world, and our minds. Nevertheless, he thinks we are basically right in maintaining that we can be teachers of language in any field of scientific knowledge, because, as I had also pointed out in my presentation, the difficulties for our students lie, not in their specialist terminology, but in the discourse into which this terminology has to be inserted. The difficulties are those "small words", the "tool words", but also, surprisingly enough, everyday vocabulary, words like downhill, as we saw.

M. Perrin then went back to Ludmilla Delorme's presentation of two sentences her medical students had been asked to translate into French, and where it was the more 
everyday words (iron, harmful, etc.) that had caused trouble, not the strictly scientific words. M. Perrin also pointed out that, paradoxically, translating scientific language into ordinary language turns out to be very difficult for the students, whereas it is relatively easy for us language teachers.

A participant, whose name I do not know, then voiced her opinion about specialist groups, such as economists for example, who quite simply take pleasure in using a certain impenetrable jargon and thus leave the layman in the dark. M. Perrin called this phenomenon "le terrorisme du jargon"; in his opinion it has always existed, and is inevitable.

Professor H. Greven feels the problem is greater than just one of jargonism: it is also a problem of pidginisation of the language (by foreign speakers of English, said M. Perrin; and by the native scientists themselves, said I). According to $\mathbf{H}$. Greven, one of our preoccupations should be the growing gap between what we might call scientific style, discourse, grammar, syntax, etc., on the one hand, and everyday English on the other.

H. Greven feels it is the ESP teacher's duty to teach scientists everyday English for their culture. The scientific vocabulary, syntax and "grammar" they know only too well! What they don't know is to speak and write proper English. I agreed, pointing out that this is a demand the scientists formulate themselves ("la viande peu salée...", as student B.B. wrote). Here the above-mentioned participant whose name I do not know came in, stating that it is not up to us to be prescriptive ("normatifs"), that it is our task to develop language awareness, and if scientists want to talk jargon, it is their problem.

According to H. Greven it is not a good idea to "keep them in their ivory tower", because they will end up being entirely alone there!

M. Perrin believes we are mixing two things here: on the one hand, there is jargon which can be deliberate and function as an instrument of terror - and we have our own - and there is jargon which is not deliberate, but just a habit of thinking and writing. And on the other hand there is pidginisation, which is the use of English as an international scientific language, written by all sorts of people all over the world, and written "in any old way". Here one does come across language phenomena which are most bizarre indeed, but which are becoming acceptable within the community. For example, "dangling participles", as in "Crossing the road a car knocked me over." Everyone who needs to understand, will understand. However, when such language is to be translated, simultaneously, the deviations become glaring.

A. Dudley-Evans concluded by saying that a challenging task for us ESP teachers is to find out what the differences between scientific and everyday language in fact are, and make our ESP students aware of those differences. We should certainly teach both scientific and non-scientific language, and not focus on one type only.

\section{NOTES}

1. Definition: "A group of symptoms of pain and dysfunction arising from the temporomandibular joint and its associated neuromusculature. Also called myofascial syndrome" . (Glossary of Periodontic Terms 1986, hereafter GPT)

2. $\mathrm{ppm}=$ pulsations per minute; $\mu \mathrm{g} / \mathrm{ml}=$ microgram(s) per millimeter 


\section{AUTHOR}

\section{ANNETTE REUMERT-KAZES}

Annette Reumert-Kazes est maître de conférences au Département de langues appliquées, section Sciences humaines de l'Université Paris 1 Panthéon-Sorbonne. annette.kazes@club-internet.fr 